\title{
Biochemical Studies on Adverse Health Effects of Arsenic and Chromium in Buffaloes
}

\author{
Himalaya Bhardwaj*, Chanchal Singh and Shashi Nayyar \\ Department of Veterinary Biochemistry, Guru AngadDev Veterinary and Animal Sciences \\ University, Ludhiana, Punjab, India-141004 \\ *Corresponding author
}

\begin{abstract}
A B S T R A C T
The present study was undertaken to assess the damage caused by heavy metals, arsenic and chromium in slaughtered buffaloes. The assessment of adverse effects of these heavy metals in tissues (Liver, kidney, pancreas, and ovary) and blood have been determined by the expression of metallothionein, antioxidants and biochemical parameters. Tissue and blood samples were collected from buffaloes $(n=50)$ from local abattoir to assess the level of arsenic and chromium. The concentration of these heavy metals was found to be significantly $(\mathrm{p}<0.05)$ higher in exposed group as compared to the control group. Malonldialdehyde (MDA) level in tissues and blood of each arsenic and chromium exposed groups were significantly $(\mathrm{p}<0.05)$ higher than the non-exposed control group. The activity of superoxide dismutase (SOD) and catalase (CAT) was found to be significantly increased $(\mathrm{p}<0.05)$ in tissues and blood of exposed group. The exposed buffaloes were found to have significantly $(\mathrm{p}<0.05)$ increased glucose, cholesterol, AST, LDH, CK, ALP, urea, and creatinine level as compared to control group. The fold change expression level of metal binding protein metallothionein (MT-2) in the heavy metal exposed tissues and blood was found to be variable expressed. liver and pancreas had maximum and minimum fold change MT-2 expression respectively. The study concluded that arsenic and chromium exposure in buffaloes could result in oxidative damage and alterations in the expression of metallothionein.
\end{abstract}

Keywords

Arsenic, Buffalo, Chromium, LDH, Metallothionein

Article Info

Accepted:

21 May 2020

Available Online:

10 June 2020

\section{Introduction}

Few of the metals are important elements required in maintaining the homeostasis in animal body. When ingested in large quantity via food chains; they cause deleterious effect on animal and human health leading to toxicity due to their potential accumulation in biological ecosystem. Heavy metals are referred to as metals with density (specific gravity) greater than five $\mathrm{g} / \mathrm{cm} 3)$. Their sources can be natural (rocks) and anthropogenic (agriculture fertilizers, industrial waste, mining) (Vanderlinden et al., 2006; Conesa et al., 2007). To fulfill increased demand of food grains and 
livestock products, modernization of industries and agriculture continues at an accelerated pace causing increase in environmental concentration of heavy metals in water, feed, air and soil. Arsenic is one of the most lethal heavy metals to ruminants, their permissible limit for organs and blood is 0-0.05 ppm and 0.04-0.5 ppm, respectively (ANZFA, 2001).

Chromium (III), on the other hand, is an essential nutritional supplement for animals and humans and has an important role in glucose metabolism. The uptake of hexavalent chromium compounds through the airways and digestive tract is faster than that of trivalent chromium compounds (Zhitkovich, 2005). The permissible limit in body for Chromium in tissues and blood are 0-0.5 ppm, 0.5-2.5 PPB respectively (ANZFA, 2001) exceeding this limit leads to the toxicity and lethal effects on animal body.

Arsenic and Chromium are mainly accumulated in soft tissues like liver, kidney and muscle causing damage and dysfunction of the organs, increase in liver enzyme and kidney parameters in plasma.

A metal binding protein Metallothionein (MT), is a ubiquitous, low molecular weight cysteine rich protein which has high affinity for essential ( $\mathrm{Zn}$ and $\mathrm{Cu}$ ) micro minerals and provide innate defense mechanism (Margoshes et al., 1957). These proteins bind tightly to heavy metals to decrease toxicity (Klaassen et al., 2009). For mammals, MTs bind zinc (Kagi, 1991), but with excess copper or cadmium, zinc can be easily be replaced by these metals (Shaw et al., 1991). MT has four isoforms in which mainly MT-1 and MT-2 isoform are present almost in all soft tissues (Masters et al., 1997; Searle et al., 1984). MT-3 isoform was expressed mainly in brain and MT-4 was detected in different epithelial cells (Uchida et al., 1991; Quaife et al., 1994).
Thus, due paucity of data related to MT2 expression in buffaloes affected with heavy metal toxicity, this approach was made to study the level of MTs in blood as marker, which could determine the exposure of heavy metals in buffaloes. The corresponding level of MTs in tissues was also studied to find out the extent of damage caused by heavy metals in various tissues.

\section{Materials and Methods}

\section{Sample collection}

The liver, kidney, pancreas and ovary tissue samples were collected on ice pack in tissue collection vials and blood samples were collected in heparinized vial from local buffalo abattoir near Ludhiana, Punjab, India. For RNA isolation buffaloes tissue samples were collected in RNALater ${ }^{\circledR}$ and blood sample in Tri-Reagent BD respectively from freshly slaughtered apparently healthy animals and store at $-80^{\circ} \mathrm{C}$ till processing.

\section{Processing of samples}

\section{Separation of plasma}

Blood samples from slaughtered buffaloes were collected in sterile tube containing anticoagulant (heparin). The samples were centrifuged at $3000 \mathrm{rpm}$, for $10 \mathrm{~min}$ at room temperature to separate plasma. The plasma samples were stored in aliquots in vial free from any mineral at $-20^{\circ} \mathrm{C}$.

\section{Preparation of tissue homogenate}

A $10 \%$ tissue homogenate was prepared in $0.1 \mathrm{M}$ Tris- $\mathrm{HCl}, \mathrm{pH}-7.5$ by using all glass tissue homogenizer with Teflon pestle followed by sonication of the homogenized tissue by sonicator. The homogenate obtained was centrifuged at $5000 \mathrm{rpm}$ for $10 \mathrm{~min}$ $(10000 \times \mathrm{g}$ for $15 \mathrm{~min})$ at $4^{\circ} \mathrm{C}$ in a refrigerated 
centrifuge. The supernatant was collected and immediately used for assaying of Arsenic and chromium determination.

\section{Preparation of $10 \%$ RBC hemolysate}

Freshly, collected heparinized blood samples after separation of plasma sediment cell was washed with $0.9 \% \mathrm{NaCl}$ solution. This process was repeated thrice then these erythrocytes obtained after washing were hemolyzed with 9-fold volume of distilled water to prepare $10 \%$ hemolysate.

Tissue homogenate and hemolysate was used to analyze reduced blood glutathione, superoxide dismutase (SOD), lipid peroxidation, catalase and glutathione peroxidase.

\section{Determination of arsenic and lead in tissues}

\section{Glassware decontamination}

All glassware used for arsenic and lead estimation were washed in detergent, soaked overnight in chromic acid and rinsed several time with triple distilled water and dried in hot air oven. Blood plasma and tissue homogenate were digested in a conical flask after adding $5 \mathrm{ml}$ triple acid $\left(\mathrm{HNO}_{3}, 70 \%\right.$ $\mathrm{HClO}_{4}$ and $\mathrm{H}_{2} \mathrm{SO}_{4}$ in 10:3:1, v/v) (Ludmila, 1976). It was covered and kept overnight at room temperature. Then solution was heated on hot plate until it becomes clear and about $0.5-1 \mathrm{ml}$ of solution is left. Then it was diluted to $10 \mathrm{ml}$ with triple distilled water and used for estimation of arsenic and chromium. The concentration of Arsenic and chromium were estimated by inductively coupled plasma optical emission spectrometer (PerkinElmer, Optima 2100DV) by using specific standard operating conditions meant for specific mineral. All the determinations were performed in duplicate.

\section{Antioxidants and biochemical parameters}

Estimation of lipid peroxidation in tissues and erythrocytes was done by the reaction of thiobarbituric acid (TBA) with malonyldialdehyde (MDA) (Placer et al., 1966). The activities of superoxide dismutase (SOD), in tissue and blood was estimated by method based on principle that the nitrobluetetrazolium inhibits superoxide dismutase with reduced nicotinamide adenine dinucleotide (NADH) mediated by phenazonium methosulphate under aerobic conditions (Nishikimi et al., 1972). The activity of erythrocytic as well as tissue glutathione peroxidase, based on the principle that glutathione peroxidase catalyzes the reaction between hydrogen peroxide $\left(\mathrm{H}_{2} \mathrm{O}_{2}\right)$ and reduced glutathione (GSH) to form oxidized glutathione (GSSG) and water $\left(\mathrm{H}_{2} \mathrm{O}\right)$ (Hafeman et al., 1974). The level of antioxidants (catalase, SOD, MDA, glutathione peroxidase (GPx), glutathione (GSH), and Vitamin $\mathrm{E}$ and $\mathrm{C}$ was determined manually.

The blood profile (glucose, total protein [TP], albumin [ALB], and globulin), lipid profile (cholesterol and triglyceride), and liver and kidney function parameters (alanine aminotransferase [ALT], aspartate aminotransferase [AST], blood urea nitrogen [BUN], and creatinine) was determined by kits (ErbaManheim). Vitamin $\mathrm{E}$ and $\mathrm{C}$ were analyzed manually.

\section{Isolation of RNA}

$0.1 \%$ DEPC treated and properly sterilized laboratory wares was used to minimize ribonuclease activity during collection of samples and all other RNA works. Isolation of RNA was done by standard protocol given in "TRI Reagents" TM RNA ISOLATION SYSTEM" for tissue and for blood TRI Reagent BD (Sigma-Aldrich, USA).The 
optical density of nucleic acid (RNA) was measured in an ultraviolet light Nano drop spectrophotometer (Thermo, USA). For quantification of RNA concentration, the readings were taken at a wavelength of 260 $\mathrm{nm}$ and $280 \mathrm{~nm}$. Pure preparations of RNA with OD260/OD280 ratio greater than 1.7 were selected for further studies (according to Sigma-Aldrich, USA guidelines).

After isolation of RNA, Reverse Transcriptase-Polymerase Chain Reaction (RT-PCR) was done for synthesis of cDNA using MMLV Reverse transcriptase 1stStrand cDNA Synthesis kit (Epicenter®). The cDNA was used immediately for real-time PCR or stored at $-20^{\circ} \mathrm{C}$ for future use. Integrated Dna Technologies (India) synthesized primers used for qPCR. Simple PCR was run at different gradient temperature $\left(60^{\circ} \mathrm{C}\right.$ to $\left.62^{\circ} \mathrm{C}\right)$ using specific MT2 primers. The oligonucleotide sequences for MT2 forward and reverse primers are. 5'A AAGATTGCAAGTGCGCCTC3' and 5' CA CTTGTCCGAAGCCCCTTT 3' respectively. RPL4 was used as the reference gene (Nygard et al., 2007) and forward and reverse primer sequence were 5'TT GGAAACATG TGTCGTGGG3' and 5'GC AGATGGCGTA TCGCTTCT3' respectively.

qPCR was performed using aliquots of cDNA and KAPASYBR FAST qPCR Master Mix (2X) kit. Each reaction was performed in a $25 \mu \mathrm{l}$ reaction volume containing $200 \mathrm{nM}$ of each amplified primer and 1ng or $2 \mathrm{ng}$ of cDNA. Expression of MT2 gene was compared with expression of RPL4 housekeeping gene along with Negative control (NTC).

The reaction was run in duplicates and carried out in CFX96 Touch $^{\mathrm{TM}}$ Real-Time PCR detection System (BIO_RAD ${ }^{\circledR}$ ) using the following cycling protocol: $95^{\circ} \mathrm{C}-3 \mathrm{~min} ; 40$ cycles of $90^{\circ} \mathrm{C}-3 \mathrm{sec}, 60^{\circ} \mathrm{C}-30 \mathrm{sec}$ and $95^{\circ} \mathrm{C}$ $5 \mathrm{sec}$. A Melting curve analysis was performed for each primer pair.

\section{Statistical analysis}

The data were analyzed using statistical package for social sciences (SPSS) software (version 16.0). Statistical comparison between means of different groups was carried out using independent t-tests.

The result of real time PCR was then calculated using: $\Delta \mathrm{Ct}=\mathrm{Ct}$ [Target]-Ct [Housekeeping] and $\Delta \Delta \mathrm{Ct}=(\Delta \mathrm{Exp})-$. ( $\Delta$ Control). After using formula $2^{\wedge^{-\Delta \Delta C t}}$ the fold change of expression of MT2 gene was calculated. Those animal in which arsenic and chromium heavy metal were found to be within permissible range have been taken as control.

\section{Results and Discussion}

Blood and tissue samples were analyzed for heavy metals. The data obtained from AAS analysis of tissue homogenate of liver, kidney, pancreas, ovary and blood plasma has been categorized as heavy metal exposed and non-exposed groups which are presented in Figure 1.

In those animals where plasma concentration of Chromium and arsenic exceeded the permissible limit, tissue samples were also processed. In exposed group the level of chromium and arsenic in liver, kidney, pancreas, ovary and blood was found to be higher than the permissible limit.

Among different tissues and blood, the level of Chromium was high in ovary $(2.3175 \pm 0.878)$ followed by Liver (1.0114 \pm 0.32$)$, Kidney $(0.6814 \pm 0.198)$, pancreas (0.5443 \pm 0.269$)$, and Blood $(0.2636 \pm 0.026)$ respectively. Whereas in Arsenic exposed group concentration (mean \pm S.E.) has been reported high in kidneys $(0.8334 \pm 0.296 \mathrm{ppm})$ followed by liver $(0.705 \pm 0.20219 \mathrm{ppm}), \quad$ pancreas $(0.5575 \pm 0.008 \mathrm{ppm}), \quad$ ovary $\quad(0.5523 \pm 0.007$ ppm) and blood (0.5321 $0.02 \mathrm{ppm})$. 


\section{Antioxidants}

Various oxidative stress parameters of buffaloes in Chromium (Cr) and arsenic (As) exposed tissues and blood has been summarized in Figure 2.

The Overall mean \pm S.E value of MDA and activity of antioxidant enzymes Like SOD and Catalase in $\mathrm{Cr}$ and $\mathrm{As}$ exposed liver, kidney, pancreas, ovary, blood were found significantly $(\mathrm{p}<0.05)$ high in all tissues and blood as compared to control non-exposed group (Figure 2).

Likewise, GPx activity of Chromium and Arsenic exposed tissue group was significantly higher than control. But activity of GPx in blood of both $\mathrm{Cr}$ and As exposed group has been found significantly lower than control group (Figure 2).

The overall mean level of GSH in erythrocytes of Chromium and arsenic exposed buffaloes was found to be $1.1543 \pm 0.205 \mu \mathrm{g} / \mathrm{ml}$ and $1.0879 \pm 0.177 \mu \mathrm{g} / \mathrm{ml}$ respectively which was lower $(\mathrm{p}<0.05)$ than the control $(2.5904 \pm 0.00896 \mu \mathrm{g} / \mathrm{ml})$ as depicted in Table 1.

The concentration of vitamin $\mathrm{C}$ in plasma of $\mathrm{Cr}$ and As exposed group was $0.7377 \pm 0.0136$ $\mathrm{mg} / \mathrm{dl}$ and $0.26545 \pm 0.0188 \mathrm{mg} / \mathrm{dl}$ respectively (Table 1). The plasma level of Vitamin E in $\mathrm{Cr}$, As metal exposed group of buffaloes was $0.38 \pm 0.01 \mathrm{mg} / \mathrm{dl}$ and $0.41 \pm 0.015 \mathrm{mg} / \mathrm{dl}$ which was found to be significantly $(\mathrm{p}<0.05)$ lower as compared to control group (Table 1).

The total immunoglobulin in plasma of $\mathrm{Cr}$ and As exposed group decreased significantly ( $\mathrm{p}<0.05)$ as compared to control (Table 1) which was reported to be $0.3016 \pm 0.042 \mathrm{~g} / \mathrm{dl}$ ) and $0.3248 \pm 0.018 \mathrm{~g} / \mathrm{dl}$ respectively.

\section{Biochemical parameters}

The glucose in $\mathrm{Cr}$ and As exposed buffaloes was $106.014 \pm 3.4 \mathrm{mg} / \mathrm{dl}$ and $109.620 \pm 1.792$ $\mathrm{mg} / \mathrm{dl}$ respectively which was significantly $(\mathrm{p}<0.05)$ higher than control (Table 1). Plasma cholesterol in $\mathrm{Cr}$ and As exposed plasma was $61.2 \pm 3.775 \mathrm{mg} / \mathrm{dl}$ and $67.5471 \pm 2.399 \mathrm{mg} / \mathrm{dl}$ respectively.

Alanine aminotransferase (ALT), Aspartate aminotransferase (AST), and Alkaline phosphatase (ALP) were found to be significantly $(p<0.05)$ higher than control. Their respective level was $80.4714 \pm 6.796$, $446.0257 \pm 55.084$ and $139.4 \pm 17.019 \mathrm{U} / \mathrm{L}$ in $\mathrm{Cr}$ exposed group and 80.4594 \pm 6.572 , $379.2553 \pm 36.331$ and $125.9882 \pm 10.588 \mathrm{U} / \mathrm{L}$ in arsenic exposed plasma respectively (Table 1).

Total protein and albumin was found to be $6.6343 \pm 0.175 \mathrm{~g} / \mathrm{dl}$ and $2.8386 \pm 0.115 \mathrm{~g} / \mathrm{dl}$ respectively in chromium exposed plasma and $6.6588 \pm 0.139 \mathrm{~g} / \mathrm{dl}$ and $2.8824 \pm 0.047 \mathrm{~g} / \mathrm{dl}$ respectively in arsenic exposed buffaloes plasma which were significantly $(p<0.05)$ lower than non-exposed control group (Table 1).

The level of urea and creatinine was $32.5706 \pm 2.105$ and $1.3112 \pm 0.059 \mathrm{mg} / \mathrm{dl}$ in arsenic exposed group and $35.5857 \pm 2.323$ and $1.2757 \pm 0.107 \mathrm{mg} / \mathrm{dl}$ respectively in chromium exposed group which was significantly $(\mathrm{p}<0.05)$ higher than the control group (Table 1).

Plasma lactate dehydrogenase (LDH) and Creatine Kinase (CK) activity in arsenic exposed group was 3239.2806 \pm 182.48 and $3015.6394 \pm 411.802 \mathrm{U} / \mathrm{L}$ respectively and in chromium exposed group these were $3389.43 \pm 365.369$ and $4474.51 \pm 566.82 \mathrm{U} / \mathrm{L}$ respectively (Table 1). 
Table.1 Metabolic profile of buffaloes environmentally exposed to heavy metals

\begin{tabular}{|c|c|c|c|}
\hline Parameter & Control Group $(n=10)$ & $\begin{array}{l}\text { Arsenic exposed group } \\
\qquad(\mathrm{n}=10)\end{array}$ & $\begin{array}{c}\text { Chromium } \\
\text { exposed group } \\
(n=10)\end{array}$ \\
\hline Glucose (mg/dl) & $51.188 \pm 0.35804$ & $109.6206 \pm 1.792 *$ & $106.0143 \pm 3.4 *$ \\
\hline $\begin{array}{l}\text { Total Cholesterol } \\
(\mathrm{mg} / \mathrm{dl})\end{array}$ & $51.526 \pm 0.55412$ & $67.5471 \pm 2.399 *$ & $61.2 \pm 3.775^{*}$ \\
\hline Triglycerides (mg/dl) & $12.306 \pm 0.15207$ & $10.4418 \pm 0.867$ & $9.6829 \pm 1.067$ \\
\hline $\operatorname{ALT}(\mathbf{U} / \mathbf{L})$ & $23.16 \pm 0.01414$ & $80.4594 \pm 6.572 *$ & $80.4714 \pm 6.796^{*}$ \\
\hline AST (U/L & $82.878 \pm 0.246$ & $379.2553 \pm 36.331 *$ & $446.0257 \pm 55.084^{*}$ \\
\hline ALP (U/L) & $72.396 \pm 0.39943$ & $125.9882 \pm 10.588^{*}$ & $139.4 \pm 17.019 *$ \\
\hline LDH (U/L) & $947.6 \pm 21.32276$ & $3239.2806 \pm 182.48 *$ & $3389.43 \pm 365.369 *$ \\
\hline CK (U/L) & $37.05 \pm 0.70711$ & $3015.6394 \pm 411.802 *$ & $4474.51 \pm 566.82 *$ \\
\hline Total proteins (g/dl) & $8.884 \pm 0.06088$ & $6.6588 \pm 0.139 *$ & $6.6343 \pm 0.175^{*}$ \\
\hline Albumin (g/dl) & $4.48 \pm 0.0114$ & $2.8824 \pm 0.047 *$ & $2.8386 \pm 0.115^{*}$ \\
\hline Urea (mg/dl) & $13.56 \pm 0.12083$ & $32.5706 \pm 2.105^{*}$ & $35.5857 \pm 2.323^{*}$ \\
\hline Creatinine (mg/dl) & $0.81 \pm 0.00707$ & $1.3112 \pm 0.059 *$ & $1.2757 \pm 0.107 *$ \\
\hline $\begin{array}{l}\text { Reduced blood } \\
\text { glutathione }(\mu \mathrm{g} / \mathrm{ml})\end{array}$ & $2.5904 \pm 0.00896$ & $1.0879 \pm 0.177 *$ & $1.1543 \pm 0.205^{*}$ \\
\hline $\begin{array}{l}\text { Total immunoglobulin } \\
\text { (g/dl) }\end{array}$ & $1.024 \pm 0.0056$ & $0.3248 \pm 0.018 *$ & $0.3016 \pm 0.042 *$ \\
\hline Vitamin E (mg/dl) & $4.0872 \pm 0.004$ & $0.41 \pm 0.015^{*}$ & $0.38 \pm 0.01 *$ \\
\hline Vitamin C (mg/dl) & $1.2 \pm 0.0256$ & $0.26545 \pm 0.0188 *$ & $0.7377 \pm 0.0136 *$ \\
\hline
\end{tabular}

*indicates significant relationship $(\mathrm{P}<0.05)$

Figure.1 Arsenic and chromium concentration (PPM) in tissues and blood samples of slaughtered buffaloes (Mean \pm S.E.)

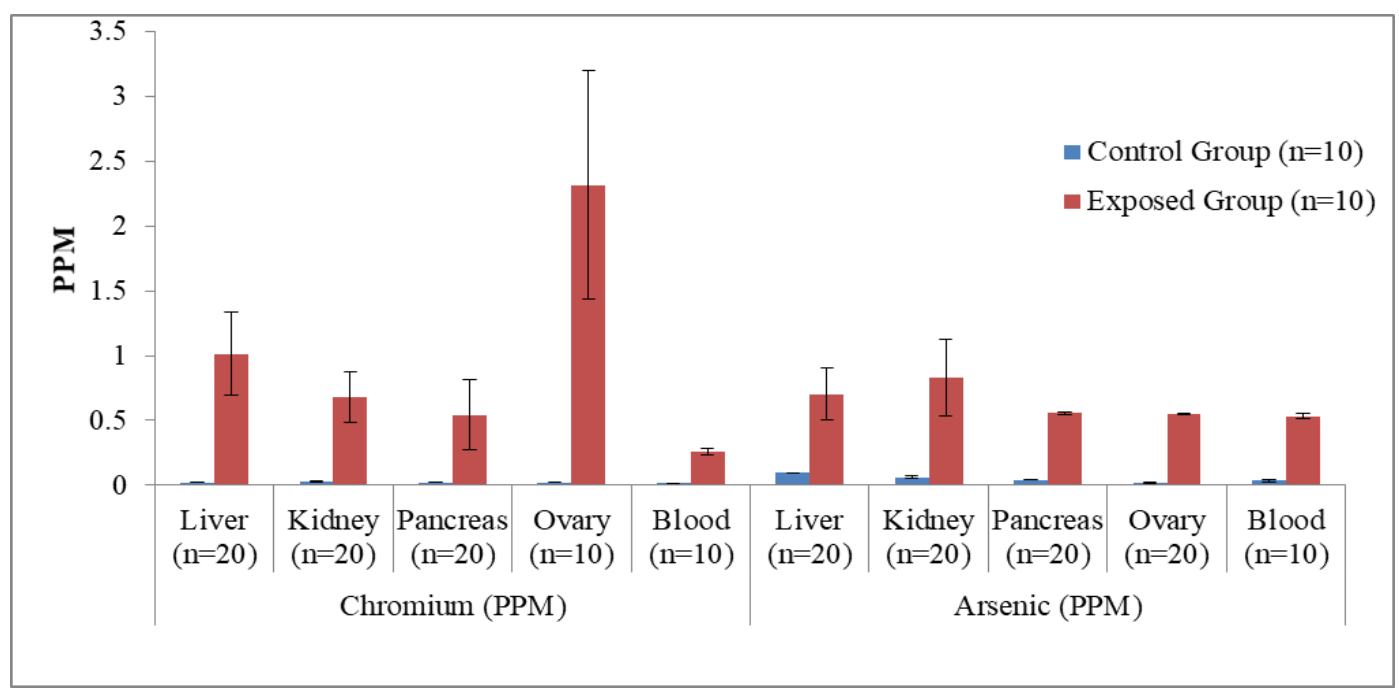


Figure.2 Oxidative stress marker in Buffaloes, (a) Catalase (U/mg). (b) Glutathione peroxidase (u/mg), (c) MDA (nmol/mg), (d) Superoxide dismutase (U/mg), (e) Reduced Blood Glutathione $(\mu \mathrm{g} / \mathrm{ml})$

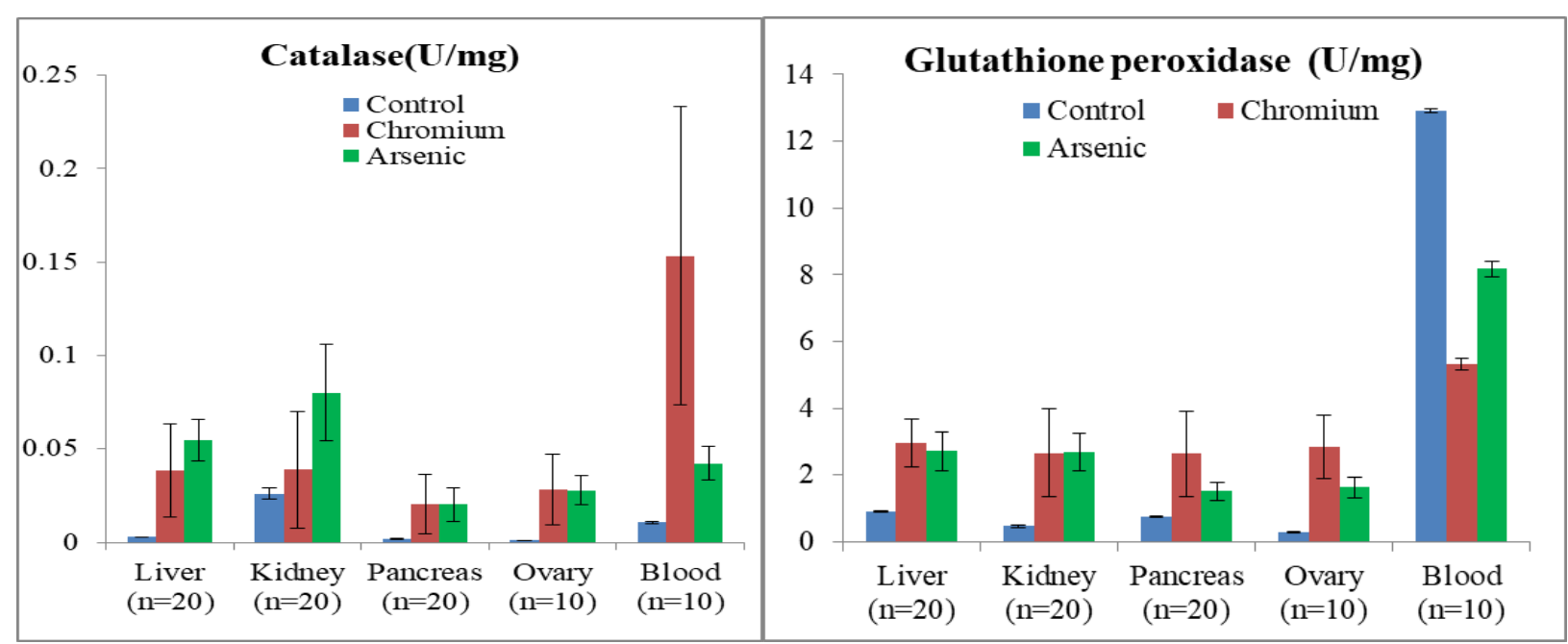

(a)

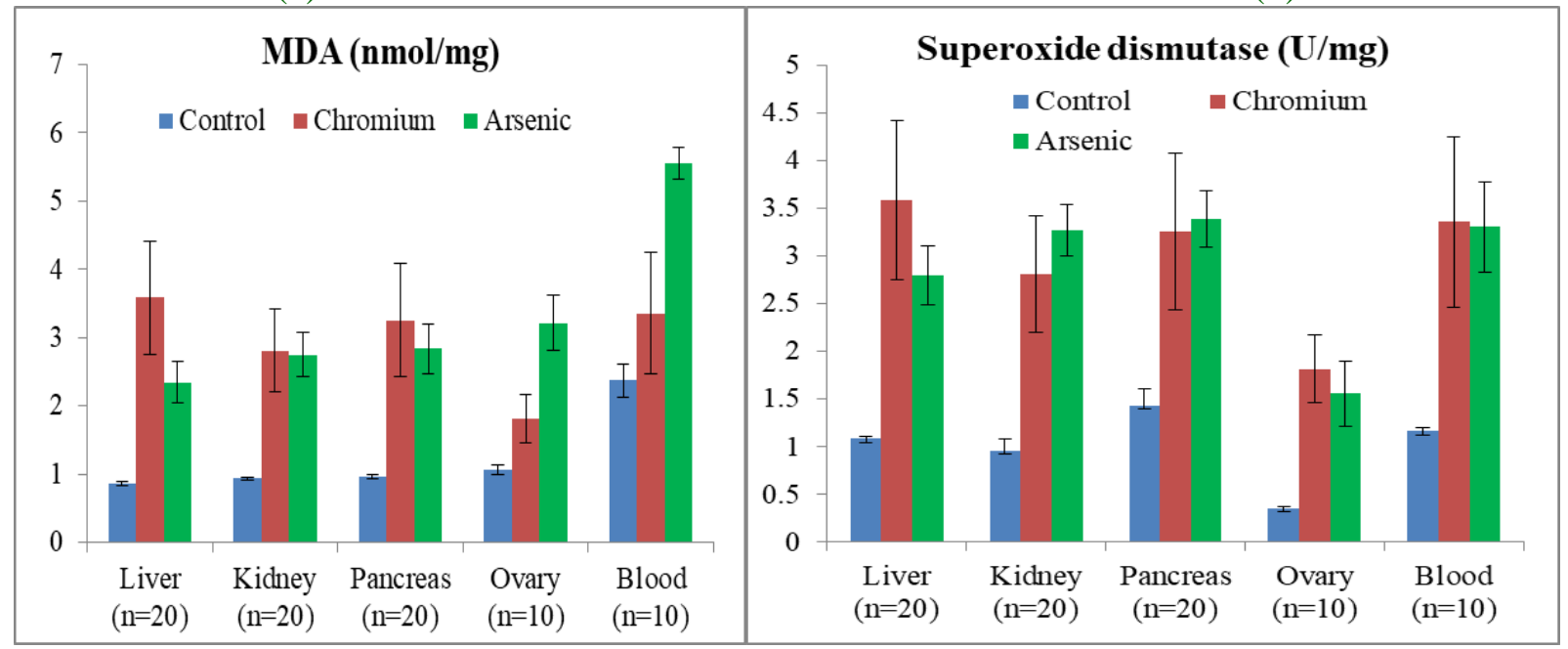

(c)

(d)

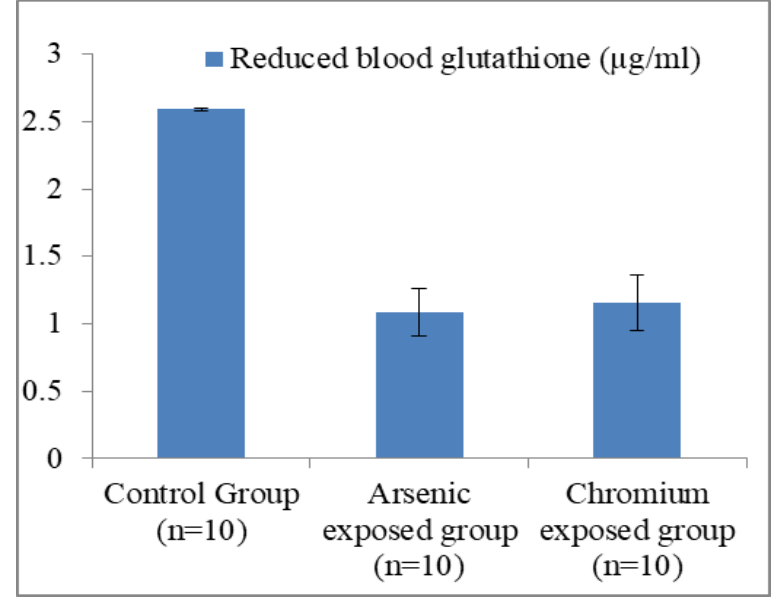

(e) 
Figure.3 Agarose gel image of PCR product of Metallothionein in different tissue and blood (well 1 liver \& 3 -kidney, well 4,5 pancreas; well 6,7 ovary and 10,11 well of blood)

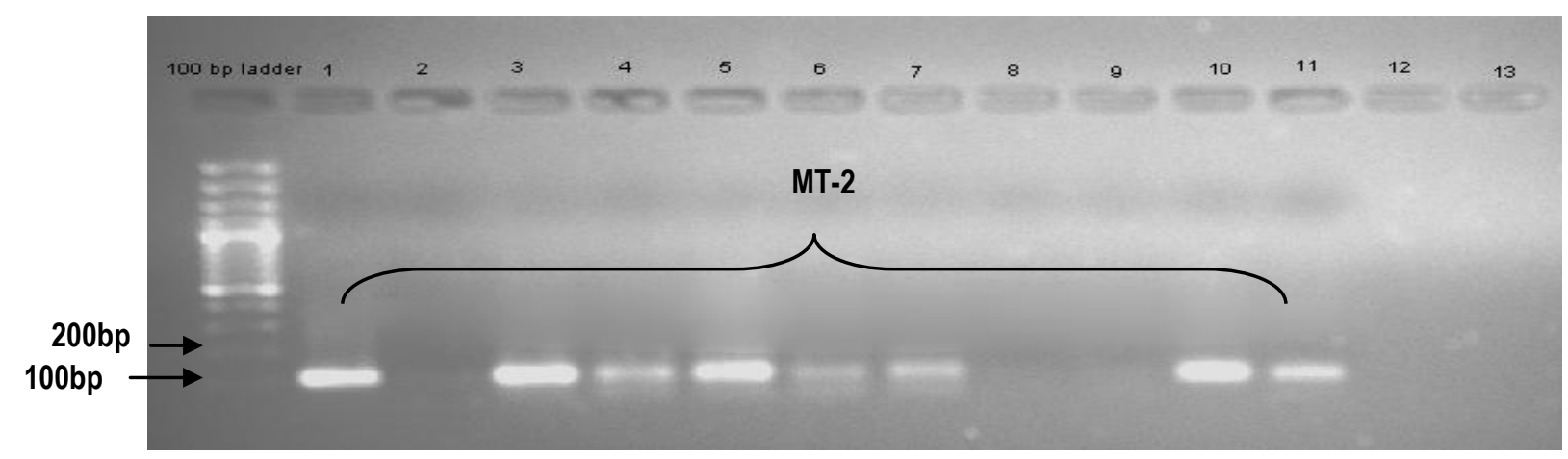

Figure.4 Fold Change Expression of Metallothionein in Chromium and Arsenic exposed organ and blood of Buffalo

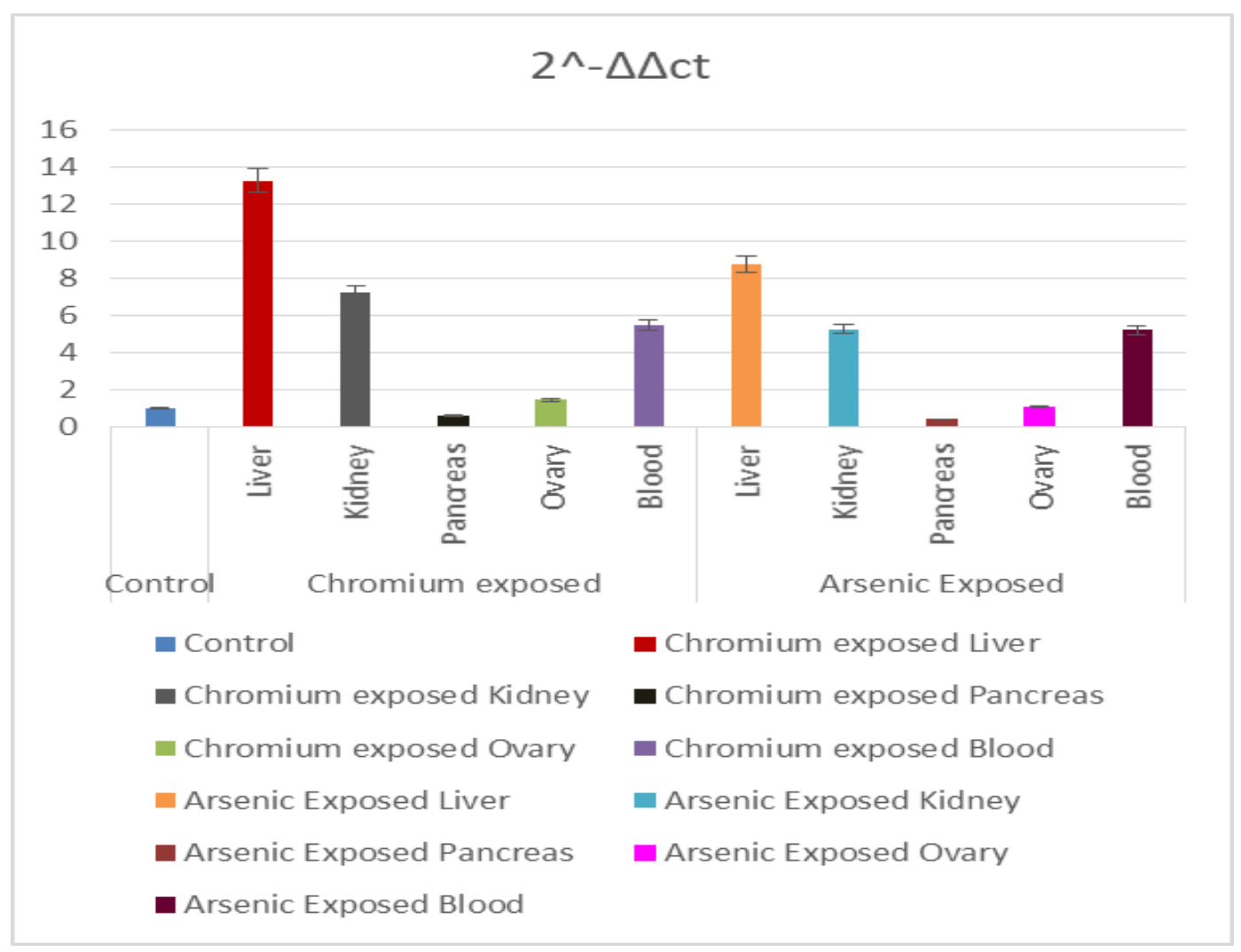

\section{Expression of MT-2}

After standardization of PCR, specific gene band (MT-2) was checked on 2\% agarose gel against $100 \mathrm{bp}$ ladder (Figure 3), the images were tasked using gel doc. Fold change expression of metallothionein in different tissue, and blood has been illustrated in figure 4. Mean $\mathrm{Ct}$ (cycle threshold) value of metallothionein-2 in arsenic exposed liver, kidney, pancreas, ovary and blood were $21.3725,19.7225$, 
$22.6175,23.845$, and 19.258 respectively. In Chromium exposed liver, kidney, pancreas, ovary and blood mean Ct (cycle threshold) value of MT-2 were 21.0475, 20.9, 24.455, 24.2 and 22.8595 respectively. Fold change expression of MT-2 in arsenic exposed animal was depicted highest in liver (8.76) followed by nearly equal expression in blood (5.18) and kidney (5.257) and downregulated expression was showed by pancreas (0.397). Among Chromium exposed organs, liver (13.246) showed maximum up-regulated expression followed by kidney (7.235), Blood (5.488) and ovary (1.4349). Fold change expression of pancreas $(0.6137)$ showed down regulation compared to control group.

The concentration of heavy metals like arsenic and Chromium have been reported to be very high in agricultural soil, fodder and water in Punjab, India (Dash et al., 2016; Yeotikar et al., 2018). These heavy metals enter the food chain and get accumulated in the system of buffaloes and other ruminants (Dhaliwal et al., 2016; Dash et al., 2016; Yeotikar et al., 2018). The present study reported high level of As and $\mathrm{Cr}$ in blood (above than permissible limit) which was similar to several other research reported these heavy metals in blood of cattle and buffalo in different part of India (Dey et al., 1997; Swarup et al., 1993, 1997; Dash et al., 2016; Yeotikar et al., 2018). High amount of Chromium and arsenic were also reported in serum samples of buffalo consuming fodder grown in land irrigated by polluted water (Raj et al., 2006; Dash et al., 2016; Yeotikar et al., 2018). Likewise, findings have also been reported where they found that the highest $\mathrm{Cr}$ concentration $(15.763 \mathrm{mg} / \mathrm{kg})$ in the liver of cow and the lowest $(0.075$ $\mathrm{mg} / \mathrm{kg}$ ) was in the meat of chicken (EISalam et al., 2013). In Current study, Arsenic were found to be high in Kidney, followed by liver, pancreas and ovary tissue.
In the current study, significant $(\mathrm{p}<0.05)$ elevated MDA level was observed in the tissues and blood of $\mathrm{Cr}$ exposed buffaloes which could be due to an increased oxidative stress of these heavy metals on tissues and blood resulting in production of free radicals which allow them to attack lipid membrane and result in an increase in lipid peroxidation. Similar findings have been reported by other authors where high level of MDA was found in blood of heavy metal exposed buffaloes (Rana et al., 2010; Dhaliwal et al., 2016; Yeotikar et al., 2018).

The activity of free radicals and oxidative stress can be assessed by endogenous antioxidants in blood and tissues (Roy et al., 2013). Free radical scavenging enzymes such as SOD, CAT, and GST are the first line of cellular defense against the toxic effects of ROS (Priscilla and Price, 2009) and they are widely used as biomarkers of oxidative stress (Uzun et al., 2010). Studies have revealed that chromium treatment has resulted in increased activities of SOD and CAT in the liver and kidneys of Rats (Patlolla et al., 2009). The increase in tissue and blood SOD activity was might be to protect cellular DNA, proteins and cell membranes from oxidative stress. Since SOD catalyzes the dismutation of superoxide anion to $\mathrm{H}_{2} \mathrm{O}_{2}$, which is in turn the substrate of CAT, this fact could explain the observed increment of the two enzyme activities. As these enzymes have a protective role against oxygen free radicalinduced damage, their induction can be understood as an adaptive response to oxidative stress.

SOD activity also reflected the intensity of the stress because of toxic action (Patlolla $e t$ al., 2009). In contrast to current findings, few other studies reported decrease in SOD and CAT activity in heavy metal exposed buffaloes that might be due to enhanced 
production of superoxide radicals during heavy metal metabolism. Different heavy metals have been reported to significantly inhibit the antioxidant enzyme activities in blood of exposed buffalo and cattle (Dhaliwal et al., 2016; Yeotikar et al., 2018).

GPx activity in exposed tissues was found to be significantly $(\mathrm{p}<0.05)$ high. Conversely, its activity in heavy metal exposed blood was significantly $(\mathrm{p}<0.05)$ low which indicates inhibition of body defense system. We also report the similar findings in accordance with the previous studies which reveal the reduction in GSH caused by oxidative stress due to increased presence of heavy metals. The decrease in concentration of GSH makes cells more prone to oxidative injuries (Kumar and Padhy, 2013). The decrease in level of GSH and increase in level of MDA were found to be in agreement with previous studies in cattle blood (Dhaliwal et al., 2016). The present findings reported significant $(\mathrm{p}<0.05)$ low levels of Vitamin $\mathrm{C}$ and $\mathrm{E}$ in the exposed group, which may be due to utilization of vitamin $\mathrm{C}$ in defense mechanism during oxidative stress (Pathan et al., 2006; Joshi et al., 2013).

The present study also explored the influence of $\mathrm{As}$ and $\mathrm{Cr}$ heavy metals on some biochemical markers. It has been found that glucose, total Cholesterol, urea and creatinine was significantly $(\mathrm{p}<0.05)$ higher in heavy metal exposed group. Elevated levels of glucose in metal exposed group might be due to disturbed glucose metabolism. The glucocorticoid system might have been hampered by exposure to heavy metals which plays important role in carbohydrates, lipid and protein metabolism (Kaltreider et al., 2001). Increased glucose and plasma cholesterol level with decrease in total protein and albumin has been reported due to high exposure of different heavy metals like arsenic and lead exposed ruminant and mice (El- Nekeety et al., 2009; Rana et al., 2010a; Mohajeri et al., 2014; Dash et al., 2018). Significant $(\mathrm{p}<0.05)$ decrease in total protein in heavy metals exposed buffaloes might be due to toxic effects of these heavy metals on protein synthesis. The reduced levels of albumin reported in the present study might be due to liver dysfunction caused by heavy metals (As, Cr) as albumin is produced by liver. The reduced levels of total protein and albumin has been reported in heavy metal exposed fishes (Panigrahi et al., 2016; Javed et al., 2017). The elevated level of creatinine and urea in heavy metal exposed buffaloes might be due to nephrotoxic metals like As, $\mathrm{Pb}, \mathrm{Cr}$ etc.

We report significant $(\mathrm{p}<0.05)$ higher level of plasma AST, ALT, ALP activities which clearly suggest the hepatic dysfunction in heavy metal exposed buffaloes. Plasma non anti-oxidant enzyme activity like LDH and CK were very high indicating muscle injuries or occurrence of anaerobic respiration due to stress in exposed buffaloes (Dash et al., 2016; Kaneko et a1., 1997; Aslani et al., 2012). Similar findings of elevated plasma hepatic and muscle enzymes due to various heavy metals have been reported in ruminants and mice (ElNekeety et al., 2009; Rana et al., 2010a; Mohajeri et al., 2014; Dash et al., 2018)that was comparable to our study.

Likewise, significant $(p<0.05)$ decreased immunoglobulin might be attributed to compromised immune system due to heavy metals (Dash et al., 2016). The decreased total immunoglobulin observed in chromium and arsenic exposed buffaloes could be caused by disturbances in immune regulation and abnormal function of white blood cells which resulted in loss of immune function due to heavy metal exposure (Chen et al., 2003; Dash et al., 2016). 
To assess the exposure of $\mathrm{As}$ and $\mathrm{Cr}$ in buffaloes metal binding protein, metallothionein-2 (MT-2) expression was studied as a biomarker. It was found that the fold expression of metallothionein-2 in arsenic and chromium exposed group was significantly $(\mathrm{p}<0.05)$ up- regulated in liver tissues followed by kidney, blood and ovary but pancreas showed down-regulated expression as compared to control group. It was also observed that chromium exposed group had higher expression of MT-2 as compared to As exposed group. The upregulation of MT-2 expression in various tissues and blood could be to prevent animal from oxidative stress by scavenging the free radicals generated due to increase in toxic/permissible level of arsenic and chromium (Ruttkay-Nedecky et al., 2013). Similar study has been reportedin arsenic exposed human beings and the findings revealed lowered expression of MT in blood as compared to tissues (Liu et al., 2007). Marked increase in metallothioneinwas also observed in liver of mice injected with lead and nickel (Šveikauskaitè et al., 2014) which was in accordance with the current study. Several studies also showed that cells which contain excessive metallothionein are resistant to heavy metal like Cadmium (Ruttkay-Nedecky et al., 2013; Karin et al., 1983). Increase in expression of this metal binding protein could prevent the tissue damage by binding with $\mathrm{As}$ and $\mathrm{Cr}$ and from oxidative stress caused by different heavy metals.

\section{Acknowledgement}

The authors are highly thankful to the Dean, College of Veterinary Science and Director of Research GADVASU, Ludhiana for providing infrastructure and facilities to conduct this study. Authors are also thankfully acknowledge the Director, School of Agricultural Biotechnology, PAU,
Ludhiana, Punjab for allowing the analysis of heavy metals on ICP-OES.

\section{References}

ANZFA (Australia New Zealand Food Authority). Wellington NZ 6036 May, 2001. Retrieved from URL: http://www.Anzfa.Gov.all.

Aslani, M.R., Heidarpour, M., Najarnezhad, V., Mostakavi, M., and Khorasani, Y.T. 2012. Lead poisoning in cattle associated with batteries recycling: High lead levels in milk of nonsymptomatic exposed cattle. Iranian Journal of Veterinary Science and Technology. 4(1): 47.

Chen, C.Y., Wang, Y.F., Lin, Y.H., and Yen, S.F. 2003. Nickel induced oxidative stress and effect of antioxidants in human lymphocytes. Archives in Toxicology. 77: 123.

Chen, Y.W., Yang, C.Y., Huang, C.F., Hung, D.Z., Leung, Y.M., and Liu, S.H. 2009. Heavy metals, islet function and diabetes development. Islets. 1(3): 169.

Conesa, H.M., Faz, A. and Arnaldos, R. 2007. Initial studies for the phytostabilization of a mine tailing from the Cartagena - La Union Mining District (SE Spain). Chemosphere. 66: 38.

Dash, S., Nayyar, S., Jindal, R., and Mukhopadhaya, C.S. 2016. Plasma enzyme activities in buffaloes (Bubalus bubalis) naturally exposed to arsenic contamination. Indian Veterinary Journal. 93: 42.

Dash, S., Nayyar, S., Sodhi, S., and Jindal, R. 2019. Terminalia arjuna modulates oxidative stress in buffaloes exposed to lead contaminated water and feed. Indian Veterinary Journal. 96(05): 1720.

Dey, S., Dwivedi, S.K., and Swarup, D. 
1997. Mineral deficiency in buffalo around a fertilizer factory. Indian Journal of Animal Sciences. 67: 780.

Dhaliwal, R.S., and Sushma, C. 2016. Effect of Heavy Metals on Oxidative Stress Parameters of Cattle Inhabiting Buddha Nallah Area of Ludhiana District in Punjab. Journal of Veterinary Science and Technology. 7: 352.

EI-Salam, N.M., Ahmad, S., Basir, A., Rais, A.K., Bibi, A., Ullah, R., Shad, A.A., Muhammad, Z., andHussain, I. 2013. Distribution of heavy metals in the liver, kidney, heart, pancreas and meat of cow, buffalo, goat, sheep and chicken from Kohat market Pakistan. Life Sciences Journal. 10(7): 937.

El-Nekeety, A.A., El-Kady, A.A., Soliman, M.S., Hassan, N.S., and AbdeiWahhab, M.A. 2009. Protective effect of Aqualegia vulgaris (L.) against lead acetate-induced oxidative stress in rats. Food and Chemical Toxicology. 47: 2209.

Hafeman, D.G., Sunde, R.A., and Hoekstra, W.G. 1974. Effect of dietary selenium on erythrocyte and liver glutathione peroxidise in the rat. Journal of Nutrition. 104: 580.

Javed, M., Ahmad, M.I., Usmani, N., and Ahmad, M. 2017. Multiple biomarker responses (serum biochemistry, oxidative stress, genotoxicity and histopathology) in Channa punctatus exposed to heavy metalloaded wastewater. Science Reports. 7: 1.

Joshi, A., Kataria, N., Kataria, A.K., Pandey, N., Asopa, S., Sankhala, L.N., Pachaury, R., and Khan, S. 2013. Stress related variations in serum vitamin $\mathrm{E}$ and $\mathrm{C}$ levels of Murrah buffaloes. Journal of Stress Physiology \& Biochemistry. 9(1): 28.

Kagi, J.H.R. 1991. Overview of metallothionein. Methods Enzymology.
205: 613.

Kaltreider, R.C., Davis, A.M., Lriviere, J.P., and Hamilton, J.W. 2001. Arsenic alters the function of the glucocorticoid receptor as a transcription factor. Environmental Health Perspectives. 109: 245.

Kaneko, J.J., Harvey, J.W., and Bruss, M.L. 1997. Clinical Biochemistry of Domestic Animals (Elsevier Inc., Oxford, United Kingdom). 22.

Karin, M., Cathala, G., and Nguyenhuu, M.C. 1983. Expression and regulation of a human metallothionein gene carried on an autonomously replicating shuttle vector. Proc. Natl. Acad. Sc. USA. 80: 4040.

Kazi, T.G., Jalbani, N., Kazi, N., Arain, M.B., Jamali, M.K., Afridi, H.I., Kandhro, G.A., Sarfraz, R.A., Shah, A.Q., and Ansari, R. 2009. Estimation of toxic metals in scalp hair samples of chronic kidney patients. Biological Trace Element Research. 127(1): 16.

Klaassen, C.D., Liu, J., and Diwan, B.A. 2009. Metallothionein protection of cadmium toxicity. Toxicology and Applied Pharmacology. 238:215.

Kumar, M., andPadhy, P.K. 2013. Oxidative stress and heavy metals: an appraisal with reference to environmental biology. International Research Journal of Biological Sciences. 2(10): 91.

Liu, J., Cheng, M.L., Yang, Q., Shan, K.R., Shen, J., Zhou,Y., and Waalkes, M.P. 2007. Blood metallothionein transcript as a biomarker for metal sensitivity: low blood metallothionein transcripts in arsenicosis patients from Guizhou, China. Environmental Health Perspectives. 115(7): 1101.

Ludmila, D. 1976. Chemical analysis by atomic spectroscopy. Varian Techtron Pvt. Ltd., Melbourn, Australia.

Margoshes, M., and Vallee, B.L. 1957. A 
cadmium protein from equine kidney cortex. J. Am. Chem. Soc., 79: 4813.

Masters, B.A., Quaife, C.J., Erickson, J.C., Kelly, E.J., Froelick, G.J., Zambrowicz, B.P., Brinster, R.L., and Palmiter, R.D. 1994. MetallthioneinIII is expressed in neurons that sequester zinc in synaptic vesicles. $J$. Neurosci. 14: 5844.

Mohajeri, G., Norouzian, M.A., Mohseni, M., and Afzalzadeh, A. 2014. Changes in blood metals, hematology and hepatic enzyme activities in lactating cows reared in the vicinity of a leadzinc smelter. Bulletin of Environmental Contamination and Toxicology. 92: 693.

Nygard, A., Jørgensen, C.B., Cirera, S., and Fredholm, M. 2007. Selection of reference genes for gene expression studies in pig tissues using SYBR green qPCR. BMC Molecular Biol. 8: 67. https://doi.org/10.1186/1471-21998-67

Panigrahi, A., Dasmahapatra, A., and Medda, A.K. 2016. Responsiveness of total plasma protein after administration of some toxic heavy metals in an Indian teleost (Clarias batrachus L.). American Journal of Bioscience. 4(5): 64.

Pathan, M.M., Latif, A., Das, H., Siddique, G.M., Vaidya, M.M., and Kushwaha, R. 2013. Assessment of oxidative stress around parturition by determining antioxidant vitamins in Mehsana buffaloes. Indian Journal of Animal Research. 47(2): 156.

Patlolla, A.K., Barnes, C., Yedjou, C., Velma, V.R., and Tchounwou, P.B. 2009. Oxidative stress, DNA damage, and antioxidant enzyme activity induced by hexavalent chromium in sprague-dawley rats. Environmental Toxicology. 24(1): 66.

Placer, Z.A., Cushman, L.L., and Johnson,
B.C. 1996. Estimation of product of lipid peroxidation (malondialdehyde) in biochemical system. Annals of Biochemistry. 16: 359.

Priscilla, D.H., and Prince, P.S.M. 2009 Cardioprotective effect of gallic acid on cardiac troponin-T, cardiac marker enzymes, lipid peroxidation products and antioxidants in experimentally induced myocardial infarction in Wistar rats. ChemBiol Interact.179: 118.

Quaife, C.J., Findley, S.D., Erickson, J.C., Froelick, G.J., Kelly, E.J., Zambrowicz, B.P., and Palmiter, R.D. 1994. Induction of a new metallothionein isoform (Mt-Iv) occurs during differentiation of stratified squamous epithelia. Biochemistry. 33: 7250.

Raj, B.G., Patnaik, M.C., Babu, S.P., Kalakumar, B., Singh, M.V. and Shylaja, J. 2006. Heavy metal contaminants in water-soil-plantanimal continuum due to pollution of Musiriver around Hyderabad in India. Indian Journal of Animal Sciences. 76: 131.

Rana, T., Bera, A.K., Das, S., Bhattacharya, D., Bandopadhyay, D.P., and Das, S.K. 2010a. Effect of chronic intake of arsenic-contaminated water on blood oxidative stress indices in cattle in an arsenic-affected zone. Ecotoxicology and Environmental Safety. 73: 1327.

Roy, D., Das, T.K., and Vaswani, S. 2013. Arsenic: it's extent of pollution and toxicosis: an animal perspective. Veterinary World 6(1): 53.

Ruttkay-Nedecky, B., Nejdl, L., Gumulec, J., Zitka, O., Masarik, M., Eckschlager, T., Stiborova, M., Adam, V., and Kizek, R. 2013. The role of metallothionein in oxidative stress. International Journal of Molecular Science. 14: 6044. 
Searle, P.F., Davison, B.L., Stuart, G.W., Wilkie, T.M., Norstedt, G., and Palmiter, R.D. 1984. Regulation, linkage, and sequence of mouse metallothionein-I and metallothioneinII genes. Mol. Cell. Biol. 4: 1221.

Shaw, C.F., Savas, M.M., and Petering, D.H. 1991. Ligand substitution and sulfhydryl reactivity of metallothionein. Methods Enzymology. 205: 401.

Šveikauskaitè, I.,Šulinskienè, J., Sadauskiene, I., and Ivanov, L. 2014. The effects of lead and nickel ions on total proteins and metallothioneins synthesis in mice liver. Biologija. 60: 17.

Swarup, D., Dwivedi, S.K., and Dey, S. 1997. Lead and Cadmium levels in blood and milk of cows from Kanpur city. Indian Journal of Animal Science. 67: 222.

Swarup, D., Dwivedi, S.K., Pandy, N.N., and Sharma, M.C. 1993. Lead in feeds and blood of bovines in varied environmental localities. Indian Journal of Veterinary Research. 2: 34.

Uchida, Y., Takio, K., Titani, K., Ihara, Y., and Tomonaga, M. 1991. The growth inhibitory factor that is deficient in the Alzheimer's-disease brain is a 68- amino acid metallothionein-like protein. Neuron. 7: 337.

Uzun, F.G., Demir, F., Kalender, S., Bas, H., and Kalender, Y. 2010. Protective effect of catechin and quercetin on chlorpyrifos-induced lung toxicity in male rats. Food Chem Toxicol. 48: 1714.

Vanderlinden, K., Ordóñez, R., Polo, M.J. and Giráldez, J.V. 2006. Mapping residual pyrite after a mine spill using non co-located spatiotemporal observations. Journal of Environmental Quality. 3: 21.

Yeotikar, P.V., Nayyar, S., Singh, C., Mukhopadhaya, C.S., Kakkar, S.S., and Jindal, R. 2018. Levels of Heavy Metals in Drinking Water, Blood and Milk of Buffaloes during Summer and Winter Seasons in Ludhiana, Punjab (India). Int. J. Pure App. Biosci. 6(2): 1265.

doi: http://dx.doi.org/10.18782/23207051.6416

Zhitkovich, A. 2005. Importance of chromium-DNA adducts in mutagenicity and toxicity of chromium (VI). Chemical Research in Toxicology. 18(1): 3.

\section{How to cite this article:}

Himalaya Bhardwaj, Chanchal Singh and Shashi Nayyar. 2020. Biochemical Studies on Adverse Health Effects of Arsenic and Chromium in Buffaloes. Int.J.Curr.Microbiol.App.Sci. 9(06): 3266-3279. doi: https://doi.org/10.20546/ijcmas.2020.906.390 